\title{
Impact of the South Atlantic Opening on the Origin and the Tectonic of the Mamfe, Douala and Rio Del Rey Sedimentary Basins, Geodynamics Implication
}

\author{
Alain Rodrigue Nzeuga ${ }^{*}$, Françoise Enyegueà Nyam¹, Robert Nouayou1, \\ James Derek Fairhead ${ }^{2}$ \\ ${ }^{1}$ Department of Physics, Faculty of Science, University of Yaounde I, Yaounde, Cameroon \\ ${ }^{2}$ School of Earth and Environment, Faculty of Environment, University of Leeds, Leeds, West Yorkshire, UK \\ Email: ^alainzeuga@yahoo.fr
}

How to cite this paper: Nzeuga, A.R., Nyam, F.E., Nouayou, R. and Fairhead, J.D. (2019) Impact of the South Atlantic Opening on the Origin and the Tectonic of the Mamfe, Douala and Rio Del Rey Sedimentary Basins, Geodynamics Implication. Open Journal of Earthquake Research, 8 , 299-312.

https://doi.org/10.4236/ojer.2019.84017

Received: June 19, 2019

Accepted: November 22, 2019

Published: November 25, 2019

Copyright $\odot 2019$ by author(s) and Scientific Research Publishing Inc. This work is licensed under the Creative Commons Attribution International License (CC BY 4.0).

http://creativecommons.org/licenses/by/4.0/

\begin{abstract}
The coastal and intracontinental sedimentary basins of Cameroon owe their origins to the opening of the South Atlantic. Among these sedimentary basins, we can mention those of Mamfe, Douala and Rio Del Rey, which are the subject of our current study. These were formed following geodynamic processes between the periods from the lower Cretaceous to the Neogene. These processes have significantly affected the basement of these basins leaving as consequences of multiple faults which would in their turn favor a rise of the magma towards the surface which then cooled to give birth to the volcanic rocks which exist there today. A study of the impact of the opening of the South Atlantic on the tectonics of these basins will be made from a geodynamic approach, relying in the first time on a qualitative and quantitative analysis of the anomaly map of the total magnetic intensity field reduced to the pole of each basin, then in a second time on the interpretation of the $2 \mathrm{D}$ geological models realized on a profile chosen on the anomaly map of the total magnetic intensity field reduced to the pole of each basin. At the end of this study, we will show that the opening of the South Atlantic has similarly impacted the structure of the three basins and the results of the spectral analysis show that the oceanic crust is thinner than the continental crust.
\end{abstract}

\section{Keywords}

Magnetism, Structural Analysis, Spectral Analysis, Magnetic Modeling, Volcanism, Geodynamics 


\section{Introduction}

The history of Cameroonian sedimentary basins and the evolution of their tectonics begin in the early Cretaceous with the break of the Pangea. From then on, following convective movements in the Earth's mantle, Earth's tectonics has evolved considerably to the formation of the seven plates and multiple islands that we know today. Another closely related phenomenon is the opening of the South Atlantic, whose evolution over time would have given rise to the Mamfe, Douala and Rio Del Rey sedimentary basins. Three tectonic phases contribute to the setting up of these basins, namely an initial rifting phase that generates extensive faults affecting the basement, followed by a drift phase that introduces growth faults and a rise of the mantle, and finally a compression phase setting up volcanic rocks. The filling of each of these basins begins in the lower Cretaceous with the intrusion of marine waters, followed by the formation of volcanic rocks formed following the great tectonic activity that accompanied their formation.

Several geological and geophysical studies have been carried out in these basins. The geological work focused on petrology and the stratigraphic and structural recognition of basins and included the works of Le Fur [1], Belmonte [2], Salard-Cheboldaeff ([3]-[8]), Njonfang [9], Regnoult [10], Pauken et al. [11], Coughlin et al. [12], Schiefelbein et al. [13], Hell et al.[14], Eseme [15], Eyong [16] , Njiké Ngaha [17], Sa'a [18], Kenfack et al. [19]. The geophysical works carried out in these basins aimed at the structural study and the realization of the anomaly and geological maps from the gravity, electrical, aeromagnetic and magnetotelluric data. These include those of Dumort [20], Collignon [21], Petters et al. [22], Fairhead et al. [23], Manguéllé-Dicoum et al. [24], Poudjom Djomani et al. [25], Benkhellil et al. [26], Ndougsa Mbarga [27], Nouayou [28], Brownfield and Charpentier [29], Nvondo Owono [30], Nguimbous et al. [31], Ndikum et al. [32], Koum et al. [33], Nzeuga et al. ([34], [35], [36]).

The goal of our work is to do a qualitative and quantitative study of the map of total magnetic intensity field reduced to the pole of each basin and use the results of the structural study carried out by Nzeuga et al. ([34], [35], [36]) for a geodynamics study of basement of Mamfe, Douala and Rio Del Rey sedimentary basins. All this allowed us to notice that during the opening of the South Atlantic, the basement of the three basins fractured in the same way along a major axis parallel to the axis of Center Cameroon Shear and that the tectonics activity was denser in the Mamfe sedimentary basin. These results also show that the oceanic crust is thinner than the continental crust and would contribute in a particular way to a thorough petrological investigation in these basins.

\section{Geographical Setting}

The Mamfe sedimentary basin is an elongated west north west-east south east trench that extends from Nigeria at its junction with the Benue Trough oriented north east-south west to the confines of the Cross-River in Cameroon where it is narrowing and ends under the Cameroon volcanic line (Figure 1). This region is 


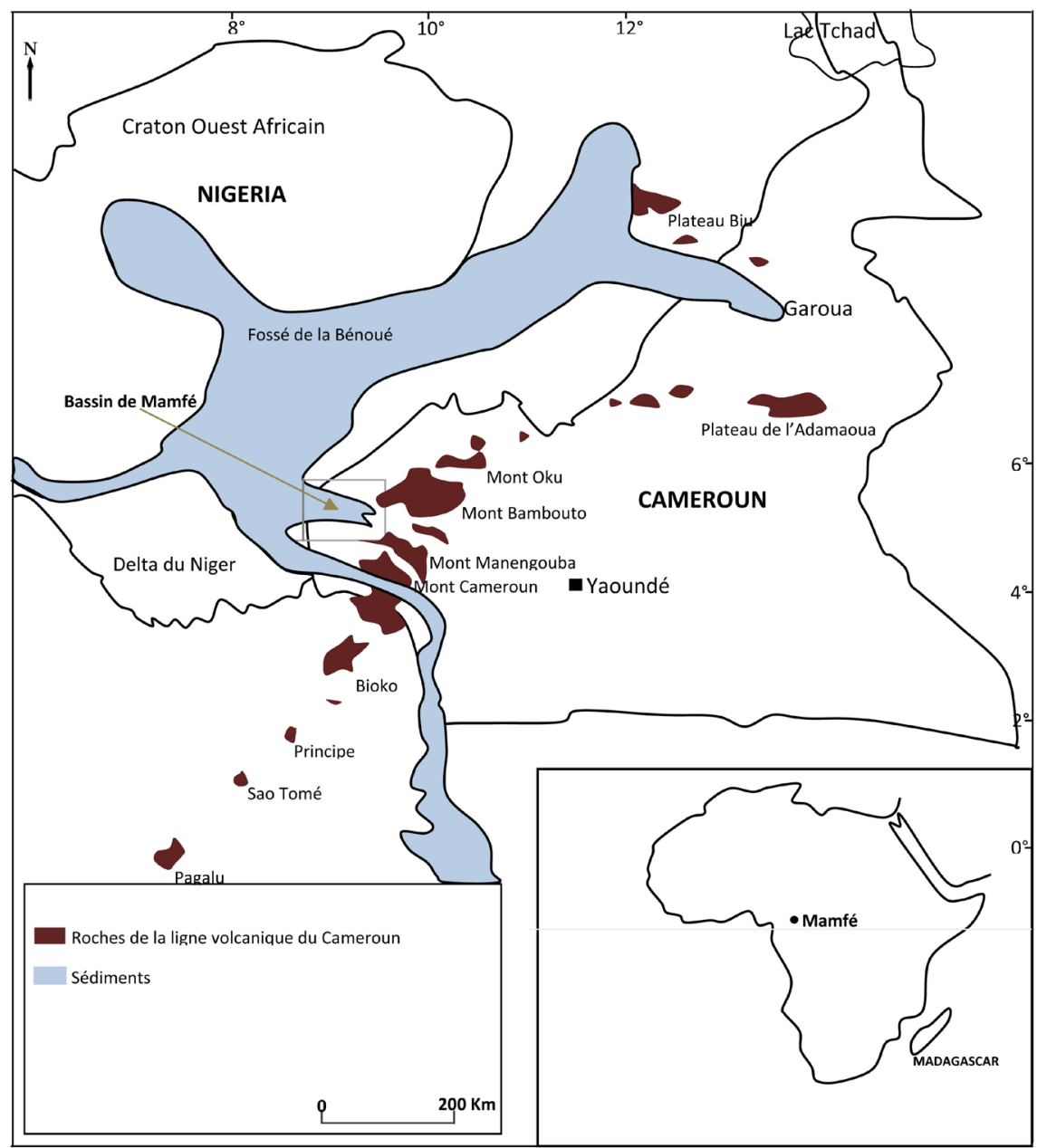

Figure 1. Location map of the Mamfe sedimentary basin [38].

located between latitudes $5.30^{\circ}$ and $6^{\circ} \mathrm{N}$ and longitudes $8.50^{\circ} \mathrm{E}$ and $9.50^{\circ} \mathrm{E}$. It is a plain which has undergone a slight bearing [20]. Following this bearing, erosion resumed leading to the establishment of a recessed relief. This low relief is limited to the South by an east-west oriented mountain range which culminates at the Roumpi mount of altitude $1764 \mathrm{~m}$. In the East, it is bounded by a segment of the Cameroon volcanic line, in the North by the Bamenda Massif, and finally, in the West, by the prolongation of the depression in the Benue tectonic trench in Nigeria [37]. At the extreme south-east of the basin, the Nda Ali massif culminates at $1260 \mathrm{~m}$, more than $1100 \mathrm{~m}$ above the Mamfé sandstone [9].

In general, the Mamfe Basin as a whole has the shape of a west-east indentation in glove finger curved towards the south at its eastern end [18].

The Douala sedimentary basin is a mangrove sedimentary plain with a relatively flat relief of very low altitude ranging from 0 to $50 \mathrm{~m}$ and very rarely up to $80 \mathrm{~m}$ [39]. It is located between latitudes $4^{\circ} 00^{\prime}$ and $4^{\circ} 06^{\prime} \mathrm{N}$ and longitudes $9^{\circ} 40^{\prime}$ and $10^{\circ} 00^{\prime} \mathrm{E}$ (Figure 2). The presence of numerous rivers and marshes gives the only relief of the region. This relief constitutes a stabilizing element of the coast, forming a barrier against the advancement of the seafront (coastal erosion) and 


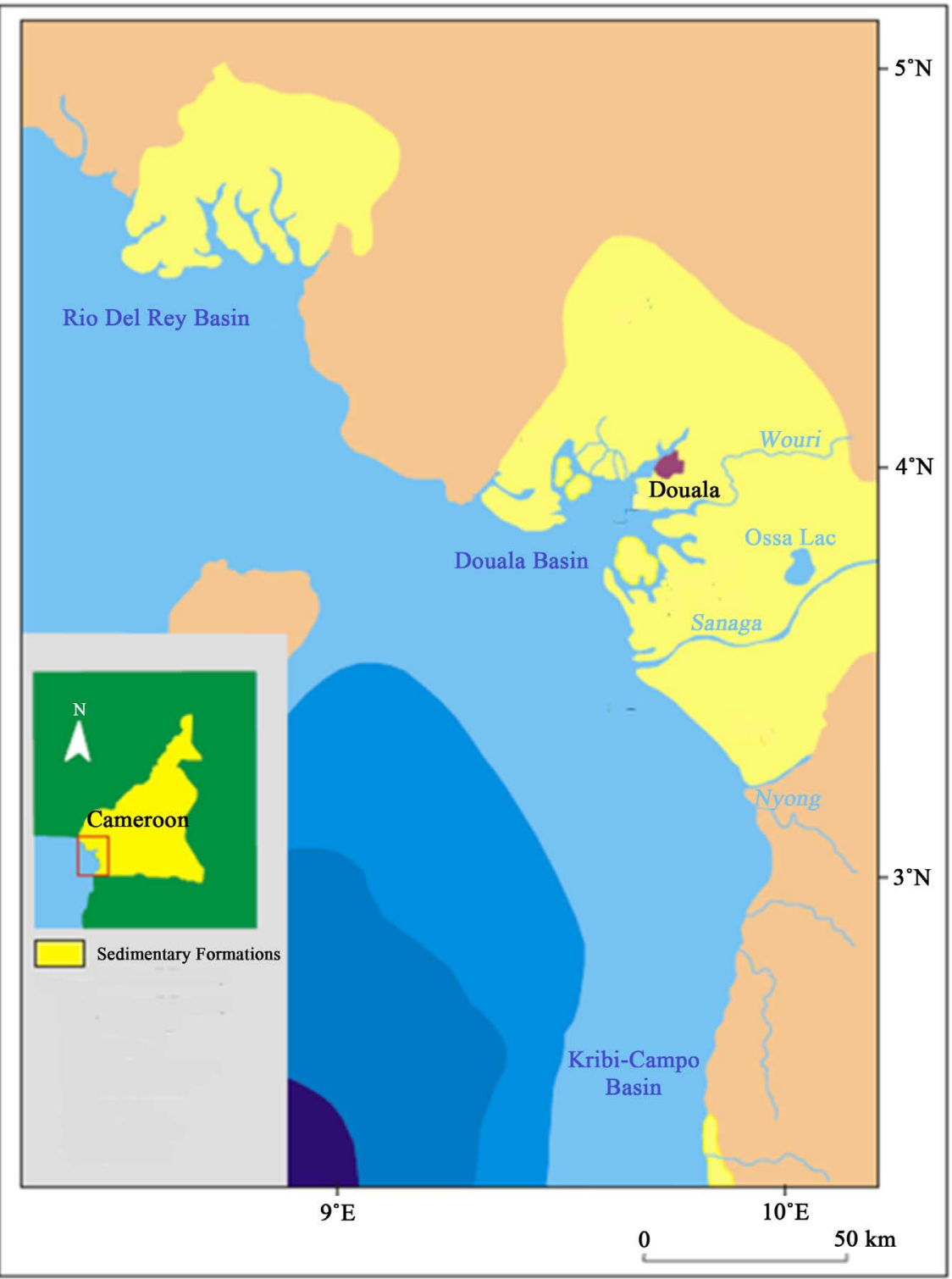

Figure 2. Location map of Douala and Rio Del Rey sedimentary basins [40].

constitutes an enormous potential in terms of woody and aquatic resources and species of marine animals.

The Rio Del Rey Basin is located on the West African margin and belongs to the Tertiary basins series of Guinea Gulf (Figure 2). It is located in the south-west Cameroon region, between latitudes $4^{\circ} \mathrm{N}$ and $5^{\circ} \mathrm{N}$, and longitudes $8.5^{\circ} \mathrm{E}$ and $9.3^{\circ} \mathrm{E}$ and is particularly framed by the Cameroon volcanic line in the East and by the Atlantic Ocean in the Southwest. It is a mangrove zone belonging to the coastal domain, consisting of long benches of solid ground a few meters high, on which rests a forest vegetation.

\section{Geological Setting}

The Mamfe basin, which is the southernmost bifurcation of the lower Benue 
trough, is intimately linked to it in terms of genesis and stratigraphy. The extension of the Cameroonian Atlantic coast basins (Campo, Douala and Rio Del Rey) towards the Benue trough is broken by the presence of the volcanic massifs of Cameroon (Figure 3). Thus, the geological history of the Mamfe, Douala and Rio Del Rey basins is linked to that of the Benue tectonic trough.

The Benue basin is a mega-structure oriented south west-north east, extending for about $1000 \mathrm{~km}$ from the Niger Delta in southern Nigeria to Lake Chad [28]. This basin whose major axis extends substantially along the $\mathrm{N} 115^{\circ}$ direction is bordered by faults in its upstream part [10]. Its lower part or southern part mixes with the oil zone of the Niger Delta basin which is located along the sea between the central and West African Atlantic coasts. This basin consists of a sedimentary part and a non-sedimentary part.

The sedimentary part consists of deposits of several thousand meters of Cretaceous sediments which are of continental fluviatile nature. The sedimentary pile consists of low to high of brechic and conglomeratic coarse sandstones, clays (mud and silicate clay), and microlitic sandstones mixed with polygenic conglomerates. All these formations are based on a granito-gneissic base.

The non-sedimentary part consists of a set of Precambrian metamorphic rocks (0 to 4 billion years old), such as gneiss, micaschist and migmatite associated with granites. It is also made up of effusive formations (volcanic) dating from the Tertiary: these are the porphyric and aphyric basalts found on the volcanic line of Cameroon.

\section{Methodology}

The methodology consists of using the aeromagnetic data collected in the three basins by GETECH Company to establish the maps of the total magnetic

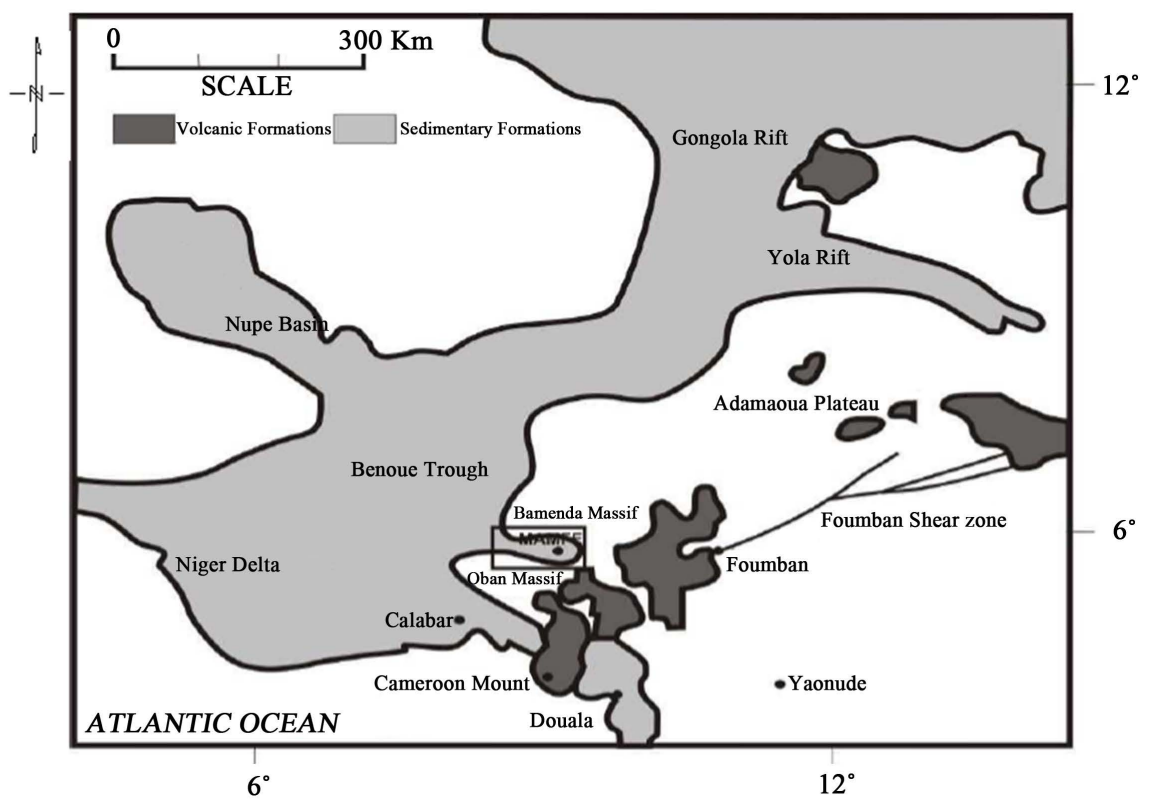

Figure 3. Rift system associated with the Benue trough [23]. 
intensity field reduced to the pole on which we will choose a profile that will be used to highlight a 2D model of the basement. Then we will use the structural maps obtained by Nzeuga et al. ([34], [35], [36]) from the same data, added to the spectral analysis to highlight the impact of the opening of the South Atlantic on the tectonics of these three basins. To achieve this, we will limit ourselves to the geodynamic approach, because geodynamics studies describe and explain the evolution of the Earth system from field observations synthesized by typical models of behavior. This method is limited to the qualitative analysis of the results of the structural study and the interpretation of the magnetic models carried out in the three basins studied. Its only advantage is that it gives an overall idea of the internal geodynamics from the results of the structural study, but remains very limited because it does not include any dynamic parameters for further study.

1) Maps of the Anomaly of the Total Magnetic Intensity Field Reduced to the Pole

The reduction to the pole operator allows determining the magnetic field that would be observed if the magnetization was vertical (inclination $\mathrm{I}=90^{\circ}$ ). These maps (Figure 4) were calculated using the Oasis Montaj software and the observed positive anomalies reach peaks of $102 \mathrm{nT}$ for Mamfe, $61 \mathrm{nT}$ for Douala and $374 \mathrm{nT}$ for Rio Del Rey. Theses anomalies are in most cases oriented west south west-east northeast, north west-south east, and south west-north east. In general, these magnetic anomalies are largely influenced by the structural direction north $75^{\circ}$ east particular to the tectonics of Cameroon.

2) Structural Maps of Mamfe, Douala and Rio Del Rey Sedimentary Basins

Figure 5 shows the structural maps of Mamfe, Douala and Rio Del Rey sedimentary basins. That of the Mamfe sedimentary basin (a) highlights several types of contacts that can be assimilated to faults (in strong lines) and intrusions of geological bodies (in broken lines). That of the Douala sedimentary basin (b) shows contacts that can be assimilated to faults (principal faults in strong lines, which would represent zones of main stress existing at the opening of the South Atlantic and secondary faults in fine lines, which would represent zones of

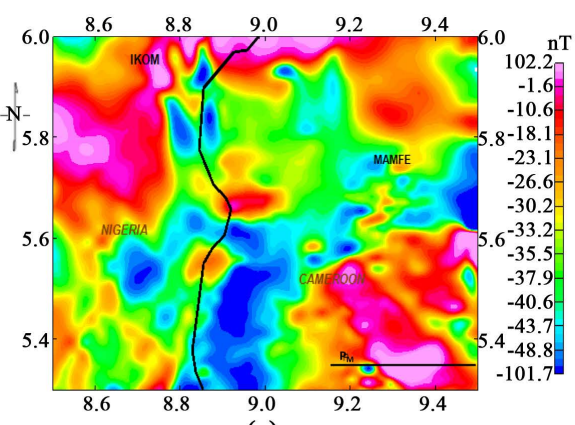

(a)

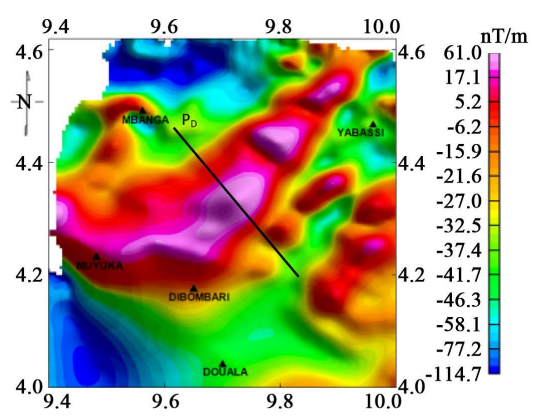

(b)

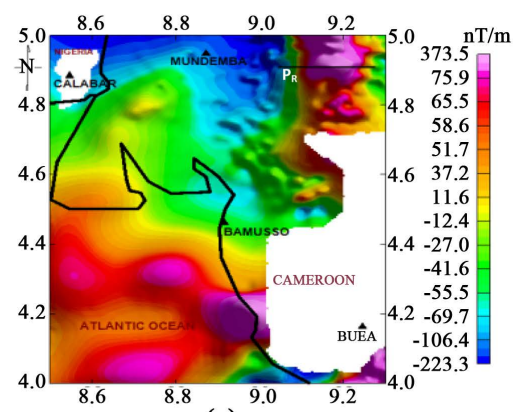

(c)

Figure 4. Maps of the anomalies of the total magnetic intensity field reduced to the pole of Mamfe (a), Douala (b) and Rio Del Rey (c) sedimentary basins on which are represented successively the profiles $\mathrm{P}_{M}, \mathrm{P}_{\mathrm{D}}$ and $\mathrm{P}_{\mathrm{R}}$ ([34], [35], [36]). 

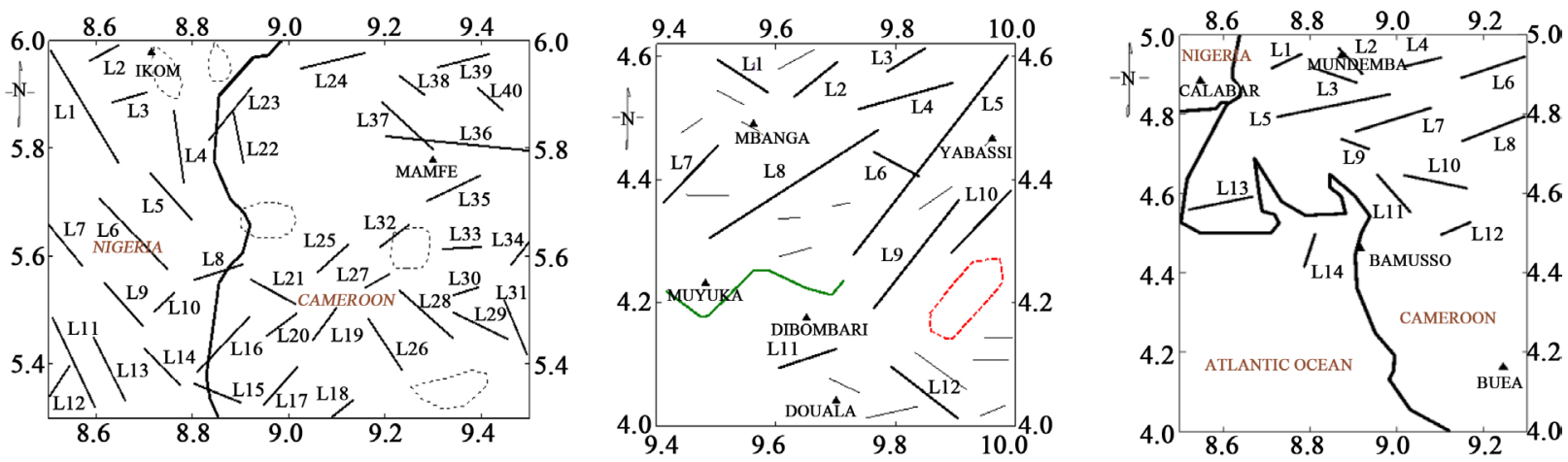

Figure 5. Interpretative structural maps of Mamfe, Douala and Rio Del Rey sedimentary basins ([34], [35], [36]).

secondary stress), geological intrusion (in red, which could be assimilated to an intrusion of igneous bodies in the sediments) and magnetic stripe (in green, which is a direct observation of magnetic ridges and troughs that can be likened to a fold). As for the structural map of the Rio Del Rey sedimentary basin (c), it highlights fault contacts type only.

In general, we can see that during the opening of the South Atlantic, the tectonics of the three study areas was subject to fracturing along three major directions namely north west-south east, south west-north east and west south west-east north east. These results are justified by the rosacea map of the fracturing directions mapped in the different basins (Figure 6).

\section{3) Spectral analysis}

The objective of spectral analysis is to provide information on the depth of magnetic anomalies. It was applied simultaneously on the $\mathrm{P}_{M}, \mathrm{P}_{\mathrm{D}}$ and $\mathrm{P}_{\mathrm{R}}$ profiles (Figure 7) and on the maps of the total magnetic intensity field reduced to the pole (Figure 8). The results show that in the Mamfe sedimentary basin, the rooftop of the magnetic anomalies is $5 \mathrm{~km}$ from the $\mathrm{P}_{\mathrm{M}}$ profile and $1.5 \mathrm{~km}$ from the map of the total magnetic intensity field reduced to the pole. For Douala and Rio Del Rey sedimentary basins, the rooftop of the magnetic anomalies is $2 \mathrm{~km}$ from the $P_{D}$ and $P_{R}$ profiles and $500 \mathrm{~m}$ on the maps of the total magnetic intensity field reduced to the pole for Douala and Rio Del Rey basins.

4) 2D modeling of the magnetic anomaly according to $P_{M}, P_{D}$ and $P_{R}$ profiles

Magnetic modeling aims to determine the geophysical characteristics of the intrusive bodies responsible for the magnetic anomalies observed in the study area. The essential parameters for this modeling are the magnetic susceptibility contrast and the depth of the anomaly. Magnetic susceptibility is obtained from information on geology and tables of average magnetic susceptibility values of rocks proposed in the scientific literature. The observed positive anomalies are basaltic intrusions in the Precambrian basement and we attributed to them a contrast of magnetic susceptibility of $0.001 \mathrm{cgs}$ for the case of the Mamfe sedimentary basin, $0.003 \mathrm{cgs}$ for the Douala sedimentary basin and $0.00985 \mathrm{cgs}$ for Rio Del Rey sedimentary basin. The depth of the anomaly according to the spectral analysis is $5 \mathrm{~km}$ for the Mamfe basin and $2 \mathrm{~km}$ for the Douala and Rio Del 

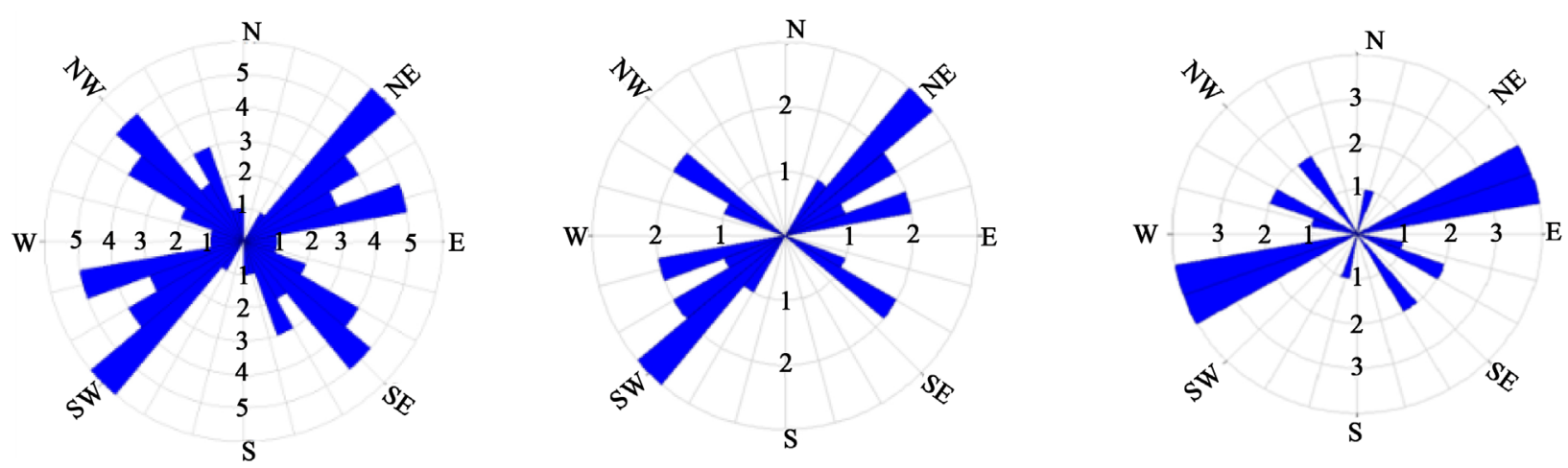

Figure 6. Rosacea of the fracturing directions mapped in the Mamfe, Douala and Rio Del Rey sedimentary basins [34], [35], [36].
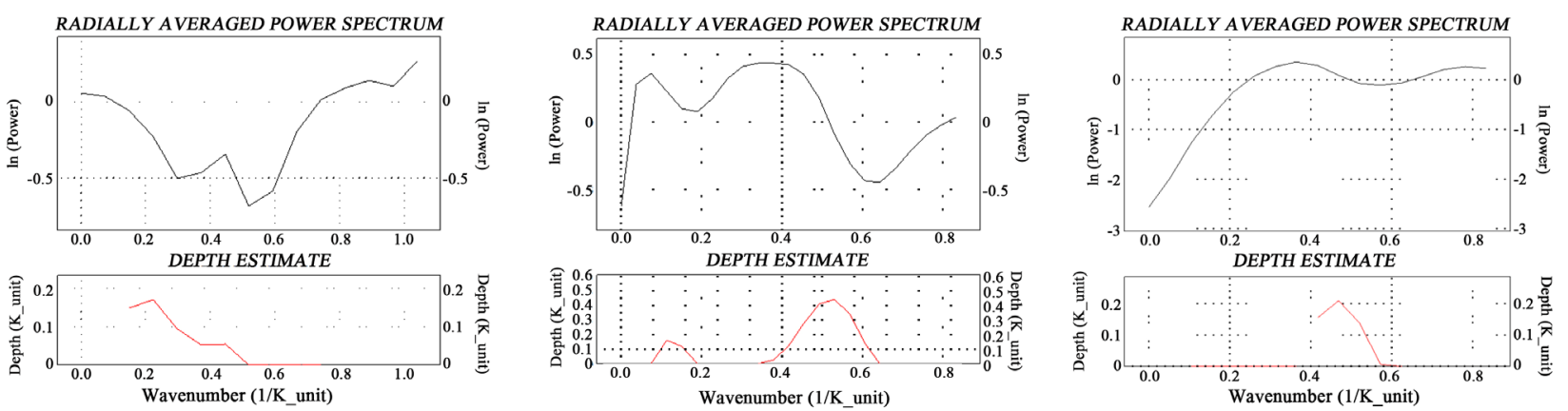

Figure 7. Spectral analysis of the anomalies around the profiles $\mathrm{P}_{M}, \mathrm{P}_{\mathrm{D}}$, and $\mathrm{P}_{\mathrm{R}}$ respectively represented on the maps of the total magnetic intensity field reduced to the pole of Mamfe, Douala and Rio Del Rey sedimentary basins [34], [35], [36].
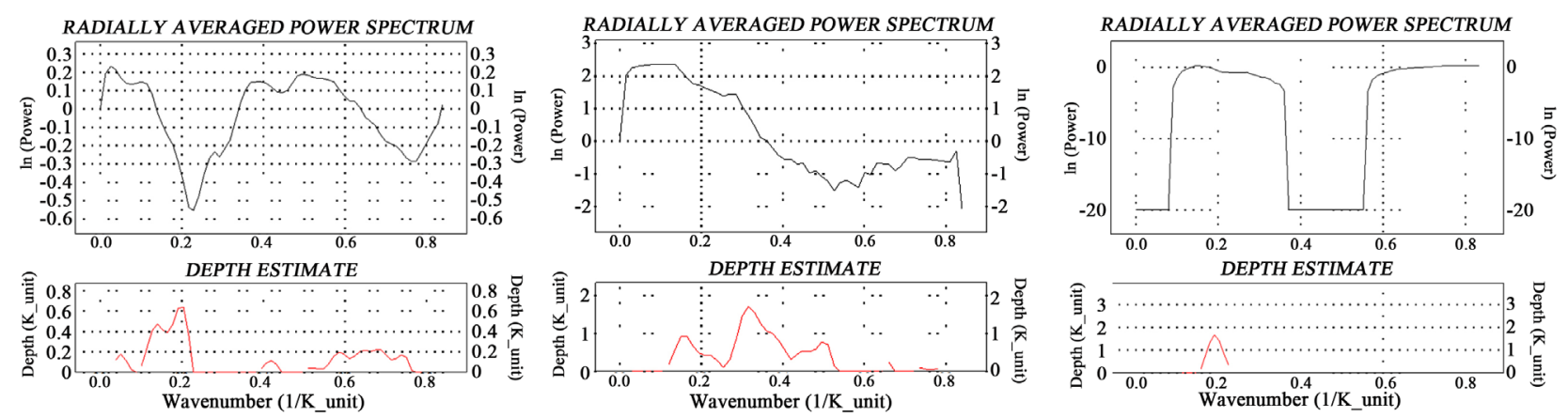

Figure 8. Spectral analysis of the maps of the total magnetic intensity field reduced to the pole, respectively of Mamfe (a), Douala (b) and Rio Del Rey (c) sedimentary basins [34], [35], [36].

Rey basins. These models (Figure 9) were calculated using the GM-SYS software of Oasis montaj with values of the geomagnetic field given by the International Geomagnetic Reference Field 32,600 nT (for Mamfe), 32,800 nT (for Douala) and 32,700 nT (for Rio Del Rey).

\section{Results}

The Mamfe, Douala and Rio Del Rey sedimentary basins are all born after the opening of the South Atlantic between the Lower Cretaceous and the Eocene. The results of the qualitative and quantitative study carried out on the maps of the total magnetic intensity field reduced to the pole of Mamfe, Douala and Rio 


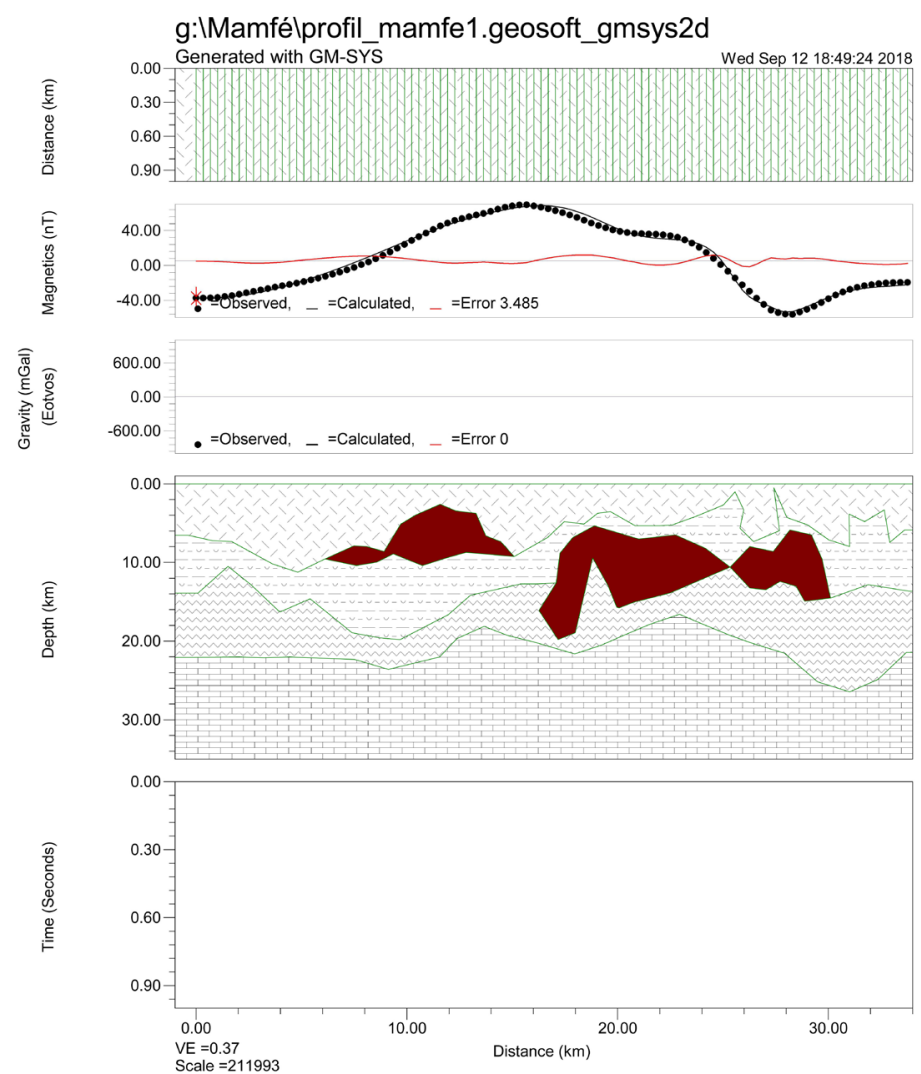

(i)
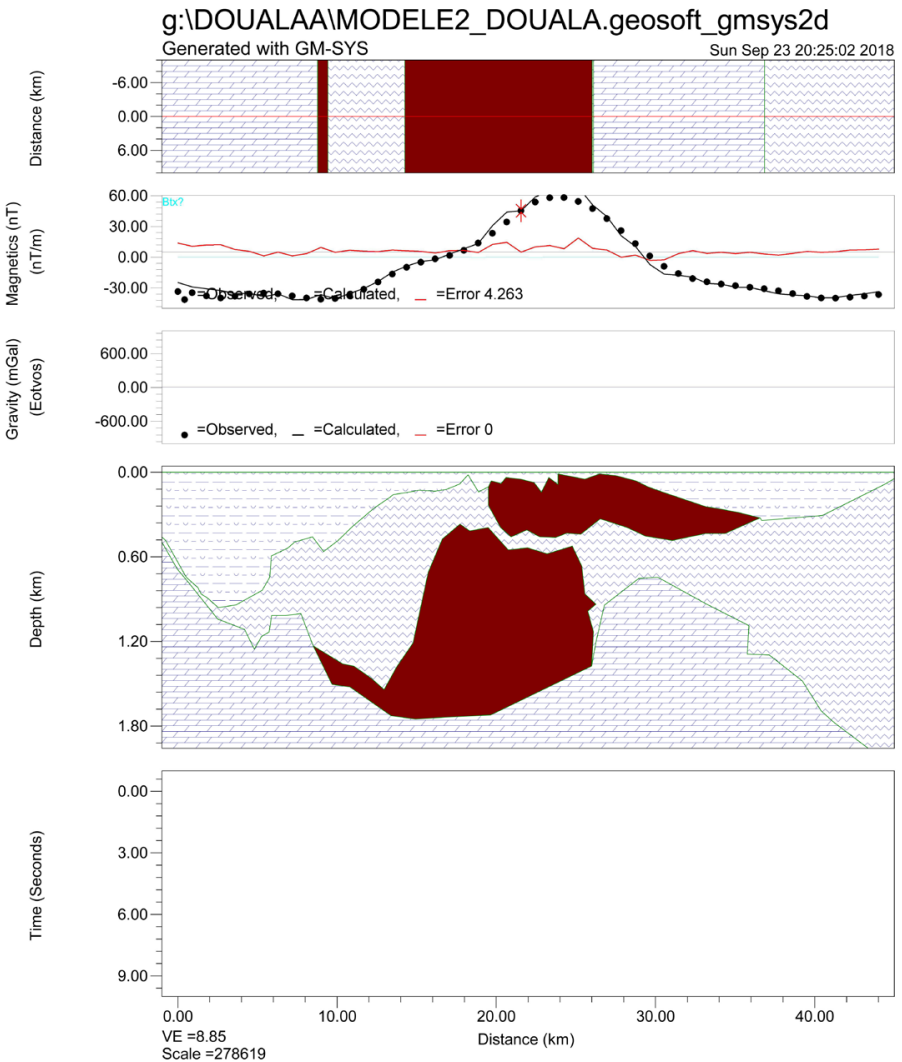

(ii) 


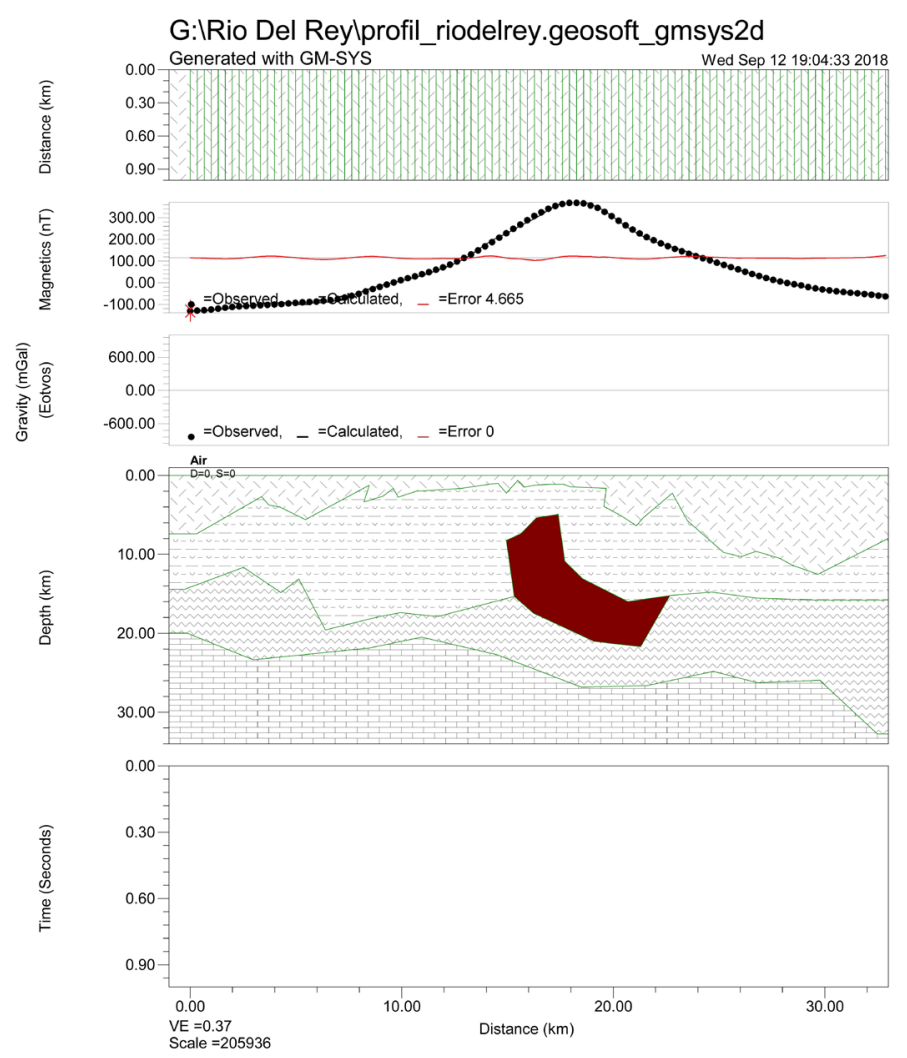

(iii)

Figure 9. Geological models of basaltic intrusion in the basement of Mamfe (i), Douala (ii) and Rio Del Rey (iii) sedimentary basins. (a) Magnetic anomalies along the profile, (b) geological model of earth ([34], [35], [36]).

Del Rey sedimentary basins will contribute to a geodynamic study of their subsoil.

The qualitative analysis of the anomaly maps of the total magnetic intensity field reduced to the pole shows that the geological relief of these basins consists of basaltic intrusions in the sedimentary rocks. These intrusions are in most cases oriented west south west-east northeast, north west-south east, south west-north east and suggest that during the opening of the South Atlantic, the tectonic movements in these basins would have caused the break of the basement and favored a rise of the magma along the above directions, which would have cooled to give birth to volcanic rocks observed in them. Also, the positive anomalies observed in the Rio Del Rey basin reach peaks of $374 \mathrm{nT}$ unlike other basins and suggest that the tectonic activity in this one is more recent.

The analysis of the structural maps shows that during the opening of the South Atlantic, the tectonics of the three basins was subject to fracturing along three major directions namely north west-south east, south west-north east and west south west-east northeast and tectonic activity was denser in the Mamfe sedimentary basin. These results corroborate those of the qualitative analysis and are also justified by the rosacea map of fracturing directions mapped in each ba$\sin$. 
The quantitative analysis by spectral analysis shows that the rooftop of the anomalies in the Mamfe basin is located at $5 \mathrm{~km}$ according to the profile and at 2 $\mathrm{km}$ on the map of the anomalies. For Douala and Rio Del Rey sedimentary basins, the rooftop of the anomalies is $2 \mathrm{~km}$ on the profile and $500 \mathrm{~m}$ on the map. Thus, since the Mamfe sedimentary basin is intracontinental and the Douala and Rio Del Rey basins are coastal, we can observe that the oceanic crust at the coast is thinner than the continental crust at the Mamfe basin.

The geological models of subsoil computed in the different basins highlight intrusions of geological body in the basement and justify the strong tectonic activity which led to the opening of the South Atlantic.

\section{Conclusions}

The opening of the South Atlantic to the lower Cretaceous is at the origin of the current structure of Mamfe, Douala and Rio Del Rey sedimentary basins. The qualitative and quantitative analysis of the anomaly maps of the total magnetic field intensity reduces to the pole, which shows that the fracturing of the basement of these basins was made along with three major directions. A geodynamic study of these basins shows that the opening of the South Atlantic influenced in the same way the tectonics of the three basins in terms of structural directions and the basement of these basins tends to split in two in the direction of the center Cameroon shear. Also, the proximity of the Mamfe sedimentary basin to the volcanic line of Cameroon justifies the strong geodynamic activity which found there compared to the Douala and Rio Del Rey basins and the rooftop of the magnetic anomalies close to the surface in Douala and Rio Del Rey basins show that the oceanic crust is thinner than the continental crust.

Then, the opening of the South Atlantic had a favorable impact on the tectonics of Mamfe, Douala and Rio Del Rey sedimentary basins and the geodynamic study of their basement compared to the tectonic activity of the Cameroon volcanic line shows that the tectonic activity in these basins is evolving. But further study integrating the dynamic parameters of the rocks of each basin would provide more accurately the results of the impact of the opening of the South Atlantic on their tectonics.

\section{Conflicts of Interest}

The authors declare no conflicts of interest regarding the publication of this paper.

\section{References}

[1] Le Fur, Y. (1965) Mission socle-Crétacé. Rapport 1964-1965 sur les indices de plomb et de zinc du golfe de Mamfé. Rapport B.G.R.M., Cameroun.

[2] Belmonte, Y.C. (1966) Stratigraphie du bassin sédimentaire du Cameroun. Proceedings of 2nd West African Micropaleontology Colloquium, Ibadan, 65-77.

[3] Salard-Chebodaeff, M. (1976) Mise en évidence de l'Oligocène dans le bassin Sédi- 
mentaire côtier du Cameroun d'après les données palynologiques. Comptes Rendus de 1 Académie des Sciences, 282, 41-43.

[4] Salard-Chebodaeff, M. (1977) Palynologie du bassin sédimentaire Littoral du Cameroun dans ses rapports avec la stratigraphie et la paléoécologie. Thèse de Doctorat d'Etat ès Sciences naturelles, Univ. Pierre et Marie Curie, Paris VI, 262 p.

[5] Salard-Chebodaeff, M. (1978) Palynoflore Maestrichtienne et Tertiaire du bassin sédimentaire littoral du Cameroun, Pollen et Spores. Musée National d'Histoire Naturelle, 215-260.

[6] Salard-Chebodaeff, M. (1979) Palynologie Maestrichtienne et Tertiaire du Cameroun. Etude Qualitative et répartition verticale des principales espèces. Review of Palaeobotany and Palynology, 28, 365-388.

https://doi.org/10.1016/0034-6667(79)90032-0

[7] Salard-Chebodaeff, M. (1981) Palynologie Maestrichtienne et Tertiaire du Cameroun. Résultats Botaniques. Review of Palaeobotany and Palynology, 32, 401-439. https://doi.org/10.1016/0034-6667(81)90021-X

[8] Salard-Chebodaeff, M. (1990) Intertropical African Palynostratigraphy from Cretaceous to Late Quaternary Times. Journal of African Earth Sciences, 11, 1-24. https://doi.org/10.1016/0899-5362(90)90072-M

[9] Njonfang, E. (1986) Un exemple de complexe pluto-volcanique tertiaire à roches basiques et intermédiaires : Le massif de Nda Ali, Sud-Ouest du Cameroun. Thèse de Doctorat 3ème cycle, Université de Yaoundé, Cameroun, 192 p.

[10] Regnoult, T.M. (1986) Synthèse géologique du Cameroun. Ministère des Mines et de l'Energie, Direction des Mines et de la Géologie, 119 p.

[11] Pauken, R.J., Thompson, J.M., Schumann, J.R. and Cooke, J.C. (1991) Geology of the Douala Basin, Offshore Cameroon, West Africa. Conference Paper, 75, 3.

[12] Coughlin, R.M., Bement, W.O. and Maloney, W.V. (1993) Petroleum Geology of the Deltaic Sequence, Rio Del Rey Basin, Offshore Cameroon. AAPG Search and Discovery Article. APPG International Conference and Exhibition, 1-5.

[13] Schiefelbein, C.F., Zumberge, J.E., Cameron, N.C. and Brown, S.W. (2000) Geochemical Comparison of Crude Oil along the South Atlantic Margin. AAPG Memoir 73, Chapter 2, 15-26.

[14] Hell, J.V., Ngako, V., Béa, A.B., Olinga, J.B. and Eyong, J.T. (2000) Rapport des travaux sur l'Etude de Reconnaissance Géologique du basin sédimentaire de Mamfé. I.R.G.M.-S.N.H., Volume 1, 20 p (Non Publié).

[15] Eseme, E. (2001) Geochemistry of Salt Spring in the Southwestern Mamfe Basin and Its Significance to Applied Sedimentology. Master's in Applied Geology, University of Buea, Cameroon, $147 \mathrm{p}$.

[16] Eyong, T.J. (2003) Litho-biostratigraphy of the Mamfe Cretaceous Basin, S. W. Province of Cameroon, West Africa. PhD Thesis, University of Leeds, Leeds, 256 p.

[17] Njiké Ngaha, P.R. (2004) Palynostratigraphie et Reconstitution des Paléoenvironnements du Crétacé de l'Est du bassin Sédimentaire de Douala (Cameroun). Thèse de Doctorat d'Etat, Université de Yaoundé I, Cameroon, 258 p.

[18] Sa'a, P.J.B. (2007) Etude sédimentologique des faciès détritiques de la moitié Est du bassin de Mamfé: Essai d'interprétation paléogéographique et intérêt pétrolier. Université de Dschang, mémoire de Master of Sciences, Dschang, $126 \mathrm{p}$.

[19] Kenfack, P.L., Njike Ngaha, P.R., Ekodeck, G.E. and Ngueutchoua, G. (2012) Fossils Dinoflagellates from the Northern Border of the Douala Sedimentary Sub-Basin (South-West Cameroon): Age Assessment and Paleological Interpretations. Geos- 
ciences, 2, 117-124.

[20] Dumort, J.C. (1968) Notice explicative sur la feuille Douala-Ouest, Direction des Mines et de la Géologie du Cameroun, 69 p.

[21] Collignon, F. (1968) Gravimétrie de reconnaissance de la République Fédérale du Cameroun. O.R.S.T.O.M., Paris, 35 p.

[22] Petters, S.W., Okereke, C.S. and Nwajide, C.S. (1987) Geology of the Mamfe Rift, S.E. Nigeria. In: Matheis, G. and Schandelmeier, Eds., Current Research in Africa Earth Sciences, Rotterdam, Balkema, 229-302.

[23] Fairhead, J.D., Okereke, C.S. and Nnange, J.M. (1991) Crustal Structure of the Mamfe Basin, West Africa, Based on Gravity Data. Tectonophysics, 186, 351-358. https://doi.org/10.1016/0040-1951(91)90368-3

[24] Manguelle-Dicoum, E., Nouayou, R., Bokosah, A.S. and Kwende-Mbanwi, T.E. (1993) Audiomagnetotelluric Soundings on the Basement-Sedimentary Transition Zone around the Eastern Margin of the Douala Basin in Cameroon. Journal of African Earth Science, 17, 487-496. https://doi.org/10.1016/0899-5362(93)90006-C

[25] Poudjom-Djomani, Y.H., Boukeke, D.B., Legeley-Padovani, A., Nnange, J.M., Atéba, B., Albouy, Y. and Fairhead, J.D. (1996) Levés gravimétriques de reconnaissance du Cameroun. ORSTOM, Paris, $33 \mathrm{p}$.

[26] Benkhellil, J., Giresse, P., Poumot, C. and Ngueutchoua, G. (2002) Lithostratigraphic, Geophysical and Morpho-Tectonic Studies of the South Cameroon Shelf. Geology, Marine and Petroleum, 19, 499-517. https://doi.org/10.1016/S0264-8172(02)00002-8

[27] Ndougsa Mbarga, T. (2004) Etude géophysique par méthode gravimétrique dans les structures profondes et superficielles de la région de Mamfé. Université de Yaoundé I, Cameroon, $255 \mathrm{p}$.

[28] Nouayou, R. (2005) Contribution à l'étude géophysique du bassin sédimentaire de Mamfé par prospections Audio et Hélio Magnétotelluriques. Thèse de Doctorat d'Etat ès Sciences, Université de Yaoundé I, Cameroon, 212 p.

[29] Brownfield, M.E. and Charpentier, R.R. (2006) Geology and Total Petroleum. Systems of the West-Central Coastal Province (7203), West Africa. U.S. Geological Survey Bulletin, 2207-B, 52 p.

[30] Mvondo Owono, F. (2010) Surrection cénozoïque de l'Ouest de l'Afrique à partir de deux exemples: Le plateau sud-namibien et la marge nord camerounaise. Thèse de Doctorat, Université de Rennes, France, 324 p.

[31] Nguimbous-Kouoh, J.J., Takam Takougang, E.M., Nouayou, R., Tabod, C.T. and Manguellé-Dicoum, E. (2012) Structural Interpretation of the Mamfe Sedimentary Basin of Southwestern Cameroon along the Manyu River Using Audiomagnetotellurics Survey. International Scholarly Research Network Geophysics, 2012, Article ID: 413042. https://doi.org/10.5402/2012/413042

[32] Ndikum, E.N., Tabod, C.T., Essimbi Zobo, B., Koumetio, F. and Noutchogwe Tatchum, C. (2014) Gravity Model for an Anomalous Body Located in the NW Portion of the Douala Sedimentary Sub-Basin, Cameroon (Central Africa). Open Journal of Geology, 4, 524-541. https://doi.org/10.4236/ojg.2014.410039

[33] Koum, S., Mvondo Owono, F., Ntamak-Nida, M.J., Njom, B. and Essama Boum, R.B. (2014) Surrection relative plio-Pléistocène de la surface côtière de la marge sud du Rio Del Rey (Cameroun) à partir de la géomorphologie quantitative sur Modèle Numérique de Terrain (MNT). Sciences, Technologies et Développement.

[34] Nzeuga, A.R., Nouayou, R., Enyegue à Nyam, F. and Fairhead, J.D. (2017) The Use 
of Aeromagnetic Data Interpretation to Characterize the Features in the Mamfe Sedimentary Basin Cameroon and a Part of the East of Nigeria. International Journal of Science and Research, 6, 617-624.

[35] Nzeuga, A.R., Nouayou, R., Njandjock Nouck, P. and Fairhead, J.D. (2017) Geophysical Features of Douala Sedimentary Basin Inferred from the Analysis of Aeromagnetic Data. International Journal of Engineering Research and Application, 7, 34-41.

[36] Nzeuga, A.R., Enyegue à Nyam, F., Nouayou, R. and Fairhead, J.D. (2019) Geophysical Study Contribution to the Rio Del Rey Sedimentary Basin Based on Aeromagnetic Data Interpretation. European Journal of Scientific Research, 151, 393-409.

[37] Mintchang, N. (2002) Contribution à l'étude pétrographique et sédimentologique des roches réservoirs du secteur occidental du bassin de Mamfé. Mémoire D.E.S.S, Université de Douala, Cameroon, 77 p.

[38] Benkhellil, J. (1989) The Origin and Evolution of the Cretaceous Benue Trough (Nigeria). Journal of African Earth Sciences, 5, 251-282. https://doi.org/10.1016/S0899-5362(89)80028-4

[39] Fometé Nembot, T. and Tchanou, Z. (1998) La gestion des écosystèmes forestiers du Cameroun à l'aube de l'an 2000. Monographies des sites critiques et annexes, Volume 2, IUCN, Yaoundé, Cameroun, 5 p.

[40] SNH (2005) Synthèse sur le Bassin du Rio Del Rey et sur le bassin de Douala/Kribi-Campo. Rapport Interne, 14 p. 